\title{
Anti-Arthritic Potential of Ethyl Acetate Extract of Stereospermum colais in Animal Model
}

\author{
Prema Suseela ${ }^{1}$, Chitra Krishnan ${ }^{2}$ \\ ${ }^{1}$ Department of Pharmaceutical Chemistry, K.K. College of Pharmacy, Gerugambakkam, Chennai, Tamilnadu, India. \\ 2 Department of Pharmaceutical Chemistry, Sri Ramachandra College of Pharmacy, Porur, Chennai, Tamilnadu, India.
}

\section{ABSTRACT}

\section{BACKGROUND}

Stereospermum colais also known as yellow snake tree is widely utilised to alleviate rheumatic pain and inflammation in the conventional medicinal system. Lapachol has been reported to be anti-inflammatory by inhibiting the production of nitric oxide (NO) and tumour necrosis factor (TNF)-alpha by means of modulating the metabolism of arachidonic acid, activation of NF-aB, suppression of nitric oxide synthase (iNOS) expression and expression of cyclooxygenase-2 (COX-2). It has also been analysed for anticancer and antioxidant activity, renal disorders, endometriosis and cardiac dysfunction. The present study investigates the antiarthritic activity of the ethyl acetate extracts of Stereospermum colais.

\section{METHODS}

The fruit rind of Garcinia indica was used to prepare extract and was quantified using liquid chromatography-mass spectrometry (LC-MS) / MS. Ethyl acetate extract showed increased content of the phytochemical constituent necessary for the treatment of arthritic pain. So, the ethyl acetate extract of bark of $S$. colais was evaluated for anti-arthritic activity by complete Freund's adjuvant (CFA). Arthritis index, body weight changes, and the biochemical analysis parameters were measured. Histopathological evaluation along with TNF-alpha and interleukin (IL)-6 assays were also studied.

\section{RESULTS}

The ethyl acetate extract showed significant reduction in arthritis index $(\mathrm{P}<0.01)$, paw swelling $(\mathrm{P}<0.01)$ and arthritic score $(\mathrm{P}<0.01)$, thereby demonstrating antiinflammatory potential. A good improvement in the biochemical parameters in extract treated animals indicates good protection against the inflammation.

\section{CONCLUSIONS}

The results show that Stereospermum colais can be used as a potential anti arthritic drug.

\section{KEY WORDS}

Rheumatoid Arthritis, Complete Freund's Adjuvant, Stereospermum colais, Ethyl Acetate, Anti-Arthritis, Meloxicam
Corresponding Author:

Dr. Prema Suseela,

Department of Pharmaceutical

Chemistry, KK College of Pharmacy,

Gerugambakkam, Chennai - 600116,

Tamilnadu, India.

E-mail:premspharm@gmail.com

DOI: $10.14260 /$ jemds/2021/213

How to Cite This Article:

Suseela $P$, Krishnan C. Anti-arthritic potential of ethyl acetate extract of Stereospermum colais in animal model. J Evolution Med Dent Sci 2021;10(14):991998, DOI: $10.14260 / j e m d s / 2021 / 213$

Submission 25-08-2020,

Peer Review 26-01-2021,

Acceptance 02-02-2021,

Published 05-04-2021.

Copyright (C) 2021 Prema Suseela et al. This is an open access article distributed under Creative Commons Attribution License [Attribution 4.0 International (CC BY 4.0)] 


\section{BACKGROUND}

Rheumatoid arthritis (RA) is a chronic inflammatory autoimmune condition that mainly affects the joints and manifests as pain, rigidity and synovitis, resulting in cartilage and bone erosion by invading the fibrovascular tissue. ${ }^{1}$ The disease affects about $1 \%$ of the world population with an annual estimated incidence of approximately 40 in 100,000 globally. ${ }^{2}$ Generally women are mostly affected twice the times as men. The onset of disease is between 45 and 65 years of age and occurs at all groups. ${ }^{3}$

The major pathological changes that occur in rheumatoid arthritis includes loss of articular cartilage, inflammation of synovial membrane and bone damage, which ultimately lead to deformation of articular surface. ${ }^{4}$ Dense cellular infiltrates primarily comprising macrophages, $\mathrm{T}$ cells and $\mathrm{B}$ cells, characterize the inflamed rheumatoid synovium. T cells play a vital role in maintaining the RA inflammation, and more Thelper (Th) cells are found in the synovial infiltrate. ${ }^{5}$ But the excessive amounts of interleukin (IL)-1, IL-6, and TNF in the synovium indicates that the activated monocyte / macrophage lineage cells also have an equally important role in the inflammatory process. Biological activities are imputed to TNF like IL-1 and IL-6 induction, neutrophil activation, enhancement of leukocyte migration and expression of adhesion molecules by endothelial cells and leukocytes. ${ }^{6}$ Cytological, morphological and molecular assessment of arthritic joints is the most rudimentary method of analysis in preclinical RA studies. Evaluation of rheumatoid arthritis using animal models is very important to facilitate the understanding of the pathophysiology of RA. It also helps to classify possible therapeutic targets, and is the beginning point for the in-vivo implementation of new therapeutic agent recognition. ${ }^{7}$

One of the widely used animal models to investigate the pathology of joint inflammation and evaluate the usefulness of preclinical therapeutic approaches is the collagen-induced arthritis (CIA). ${ }^{8}$ It shares a lot of resemblances in pathological and immunological activities, such as systemic joint involvement, damage of peripheral joints, synovitis, cartilage along with bone erosions, and inflammatory cell infiltration of the synovium. ${ }^{9}$ The options for treating the RA is limited as there are only few specific antirheumatic agents in current use. NSAIDs, glucocorticoids and disease-modifying antirheumatic drugs (DMARDs) are the major non-biologic pharmacological treatment groups for RA most of which are slow-acting, and some associated with significant toxicity hazards. ${ }^{10}$ As a result of these limitations, a growing number of patients have begun to turn to care using natural products to relieve RA symptoms. Nevertheless, challenges in assessing the effectiveness of these items as well as limited knowledge on their mode of action are among the reasons for public and professional scepticism. The therapeutic approach to arthritis therefore allows the treatment to be cost-effective, long-lived, and with minimal or less side effects. The drugs should also be capable of suppressing the expression of inflammatory and proinflammatory cytokines, thereby preventing joint harm. ${ }^{11}$

Stereospermum colais (Bignoniaceae), widely known as Yellow snake tree in English is a bigger and straight stemmed deciduous tree, that grows around $18-30 \mathrm{~m}$ high and $2.8 \mathrm{~m}$ in girth seen in damp areas of India up to an elevation of about $1200 \mathrm{~m}^{12}$ It is used in ayurvedic medical system to treat vomiting, leprosy, fevers, mitigation, kapha, itching, diabetes, and clean contaminated wounds. ${ }^{13}$ It also shows antidiarrhoea activity, analgesic activity, antioxidant activity, wound healing activity, antibacterial, antifungal activity. ${ }^{14-18}$ The juice of the leaves can be mixed with lime juice to treat maniacal cases. Decoction of the leaves has antipyretic properties and is used to treat chronic dyspepsia and also in the treatment of asthma and cough. ${ }^{19}$ Stereospermum colais is also used as diuretic, lithotrophic, cardio tonic, anti-pyretic, expectorant, aphrodisiac, anti-inflammatory, antibacterial, febrifuge, anti-emetic, rheumatalgia, malarial fever, wound, asthma and cough. The complete parts of the tree can be used, including the root which is the main ingredient in few ayurvedic formulations. In the ayurvedic literature it is said to possess the properties of treating pain and inflammation. Therefore, the present study investigates the anti-arthritic activity of the ethyl acetate extracts of Stereospermum colais.

\section{METHODS}

\section{Study Duration}

The duration of the animal study was one month (April 2012). Total study duration was 2012 to 2013.

\section{Plant Material}

The plant bark of the stem of $S$. colais was collected in the month of September 2010 in Porur, Tamil Nadu, India. The botanical authentication and identification were performed by plant expert Dr. P. Jayaraman, Director, Plant Anatomy Research Centre (PARC), Tambaram, Chennai. A voucher specimen No. PARC / 2010 / 2029 has been deposited for further reference. The bark materials were shade dried and coarsely powdered.

\section{Preparation of Extract}

The bark was shade dried, coarsely powdered and allowed to dry. For extraction, cold maceration method was used. Solvents of increasing polarity like n-hexane, chloroform, ethyl acetate and ethanol were utilised. After $72 \mathrm{hrs}$. of maceration process, the remaining content was filtered. Acetone extraction was performed separately by defatting with nhexane solvent. Every time before extraction with the next higher polarity solvent, the marc was dried. The extracts were concentrated by distilling solvent after full extraction and then evaporated into dryness in the water bath. The percentage yield of ethyl acetate extract $(64 \% \mathrm{w} / \mathrm{w})$ was calculated on the air-dried basis.

\section{Phytochemical Screening}

To classify the chemical constituents, the bark extracts obtained were subjected to preliminary phytochemical screening. ${ }^{20}$

\section{Acute Toxicity Study}

Acute oral toxicity study of bark extracts of Stereospermum colais was carried out according to the Organization for Economic Co-operation and Development guidelines 423.21 


\section{Animal Procurement and Maintenance}

Male Wister rats (150 -250 g) were procured from Centre for Toxicology and Developmental Research (CEFT), SRU. The animals were maintained in animal house at a room temperature of $20 \pm 2^{\circ} \mathrm{C}$, with a relative humidity of $50 \pm 5 \%$ and alternating $12 \mathrm{hr}$ dark-light. The animals had free access to standard laboratory feed and water ad libitum. The rats were acclimatised to the environment for 1 week prior to experiment use. The study was approved by the standing institutional animal ethics committee (IAEC: No: XIII / SRU / 95 / 2008) of the Sri Ramachandra University.

\section{Induction of Arthritis}

Animals were injected with $0.1 \mathrm{ml}$ of complete Freund's adjuvant intraperitoneally into each rat's right hind paw to cause arthritis. ${ }^{22}$ The rats were categorised into groups of 6 animals: group I, the arthritic control group and group II, the non-arthritic control group. Group I received only CFA intraperitoneal injection, but group II (incomplete Freund's adjuvant group (IFA)) received $0.1 \mathrm{ml}$ IFA intraperitoneal injection (sterile paraffin oil). Erythromycin ethylsuccinateEAESC (200 mg / Kg and $400 \mathrm{mg} / \mathrm{Kg}$ ) and standard meloxicam $(0.1 \mathrm{ml} / \mathrm{Kg})$ were injected to the rats in the different groups respectively. Water displacement plethysmograph was used to calculate paw volume for both the ipsilateral (injected paw) and the contralateral paw (noninjected paw) before administration of intraperitoneal CFA injection (day 0) and every week. ${ }^{23}$ The oedema element of inflammation was determined by the difference in foot volumes on day 0 and day 28. Two sets of experiments were carried out, one is curative, and another is prophylactic. After the intraperitoneal administration of $0.1 \mathrm{ml}$ CFA, there was onset of arthritis and drug was administered on day 9. The drugs were given on day 0 in a prophylactic regimen and CFA was administered intraperitoneally 24 hours later. The animals were grouped as:

- Group 1- Non-control / IFA (intraperitoneal injection of $0.1 \mathrm{ml}$ of IFA)

- Group 2 - Arthritic control/ CFA (intraperitoneal injection of $0.1 \mathrm{ml} \mathrm{CFA}$ )

- $\quad$ Group 3 - EAESC $200 \mathrm{mg} / \mathrm{Kg}$ respectively from day 9 (curative) and from day 0 (prophylactic)

- Group 4 - EAESC $400 \mathrm{mg} / \mathrm{Kg}$ respectively from day 9 (curative) and from day 0 (prophylactic)

- $\quad$ Group 5 - Meloxicam $(0.1 \mathrm{ml} / \mathrm{Kg})$

The ipsilateral and contralateral paw volume scores were independently standardised from the value at day 0 as a percentage change and then the average was taken for each treatment group. The extract and standard were suspended in $0.5 \% \mathrm{CMC}$ and the drugs were freshly prepared.

\section{Arthritis Index}

Every week the rats were evaluated for arthritis. The following grading method was used to analyse the physical symptoms of arthritis. $^{24} \quad 0=$ Paw is normal; 1 = Toe erythema; 2 = Swelling and erythema of paws; 3 = Ankle swelling; $4=$ Whole leg swelling thus unable to bend it. The achievable score to the maximum is 16. By adding the four scores of individual paws the arthritis index of each rat is calculated. When at least one non-injected paw was seen inflamed it shows that the animal is sensitized and considered to have arthritis. ${ }^{25}$

\section{Measurement of Body Weight}

For every rat the weight of the body was recorded prior and every week after inoculation of the adjuvant. The intake of food and weight gain is measured throughout the arthritic period. The change in body weight in arthritic rats is calculated by determining the body weight at each day and that of day 0 . Percentage of body weight changes was calculated.

\section{Measurement of Paw Volume Changes}

Following adjuvant inoculation, the hind paw volumes before and after the adjuvant administration were determined using water displacement plethysmometry. ${ }^{26}$ Variations in the volumes of hind paws were estimated from the measurements on day 0 .

\section{Biochemical Analysis}

All the animals were anaesthetised, blood withdrawal was done for serum separation by retro-orbital puncture and collected in plain and EDTA containing tubes respectively at the end of experiment, on the $28^{\text {th }}$ day. Biochemical examination like blood urea nitrogen (BUN), creatinine (CR), total protein (TP), alanine aminotransaminase (ALT), aspartate aminotransaminase (AST), alkaline phosphate (ALP), and c-reactive protein (CRP) in blood and in liver superoxide dismutase (SOD), reduced glutathione (GSH), lipid peroxidation (LPO), glutathione peroxidise (GPX), and protein was conducted on the homogenised samples. All the analysis was done by using standard diagnostic kit (Transasia BioMedical Ltd., Mumbai) protocol provided by the vendor was followed for the all the assay.

\section{TNF-Alpha and IL-6 Assays}

After disease induction, animals were immolated on the $28^{\text {th }}$ day and blood samples were withdrawn to distinguish adjuvant non-treated and SNP-treated arthritic rats. Enzymelinked immunosorbent assay (ELISA) kits (M / s. Bender Medsystems $\mathrm{GmbH}$, Vienna, Austria) were used to determine serum levels of TNF-alpha and IL-6. In the wells of the microtiter strips, antibodies specific to rat TNF-alpha and IL-6 were coated and samples including standards of established rat TNF-alpha and IL- 6 were incubated, washed and pipetted into the wells. The colour intensity was measured at $450 \mathrm{~nm}$ with a correction wavelength of $630 \mathrm{~nm}$.

\section{Histopathological Examination}

The ankle joint tissues from control group and arthritic and treated rats were excised and fixed in 10 percent buffered formalin. It was then decalcified using 10 percent EDTA solution, embedded in paraffin, sectioned and stained with haematoxylin and eosin (H \& E stain), for examination under a light microscope. Mononuclear inflammation, vascular proliferation, oedema, synovial hyperplasia and vasculitis causing vessel wall fibrinoid necrosis in periarticular and subcutaneous adipose tissue were the test parameters. A 
pathologist, blind to the specimens, conducted the pathological assessment randomly.

\section{Statistical Analysis}

Data were presented as the mean \pm standard error of deviation. The oedema volume measured in the various treatment groups was compared and contrasted by the twoway ANOVA and Dunnet multiple comparison tests with group I and group II. In order to determine the variations between the effects of different doses, significance tests have also been calculated.

\section{RESULTS}

\section{Preliminary Phytochemical Screening}

The preliminary phytochemical and biochemical screening of the bark ethyl acetate extract of Stereospermum colais reveals the presence of proteins, amino acids, saponins, flavonoids, phenolic compounds, tannins, terpenoids and steroids.

\section{Acute Toxicity Study}

There was no evidence of mortality for up to 24 hours and behavioural changes toxicity signs were observed in all animals. EAESC extract was safe up to a $2000 \mathrm{mg} / \mathrm{Kg}$ body weight of animals. This research was therefore performed at doses of 200 and $400 \mathrm{mg} / \mathrm{Kg}$ body weight of Wistar rats.

\section{Body Weight Changes in Experimental Animals} There were significant body weight changes observed in the arthritic control group animals when compared to the normal and extracted animals in both prophylactic phase and curative phase present in Table 1.

\section{Effect on Paw Volume}

In the present analysis, the phases of adjuvant arthritis investigated were the acute and chronic phases corresponding to days $0-10$ and $10-18$ respectively after adjuvant inoculation. An important $(\mathrm{P}<0.05)$ effect of drug therapy has been demonstrated by the two-way ANOVA (treatment Xtime). The total oedema generated by each treatment is expressed as the AUC of the time course curves in arbitrary units. At the ipsilateral (injected paw) around $4-6$ days, all arthritis control animals showed acute inflammatory oedema followed by subsequent polyarthritis process beginning around day $10-12$. On day 12 , with systemic inflammation, the improvement of inflammatory oedema in the non-injected paw was evident. The paw volume of the non-inflamed control group injected IFA did not alter significantly during the 28-day trial. In comparison to standard meloxicam, EAESC $200 \mathrm{mg} /$ $\mathrm{Kg}$ and $400 \mathrm{mg} / \mathrm{Kg}$ have significantly modified the course of time $(\mathrm{P}<0.05)$ and significantly reduced oedema in the ipsilateral paw (200 $\mathrm{mg} / \mathrm{Kg}$ ) by percentage inhibition. This meloxicam and EAESC group completely presented the spread of the arthritis from the injected to the non-injected paws of the treatment animals. EAESC $400 \mathrm{mg} / \mathrm{Kg}$ did not exhibit significant anti-arthritic activity. EAESC $200 \mathrm{mg} / \mathrm{Kg}$ and 400 mg / Kg did not show any significant effect compared to standard data present in Table 2.

\section{Effect on Arthritic Score}

For the arthritic groups with erythema and increased hind paw swelling, especially for the EAESC $200 \mathrm{mg} / \mathrm{Kg}$ body weight group and for the anti-arthritic groups $400 \mathrm{mg} / \mathrm{Kg}$ and meloxicam $(0.1 \mathrm{ml} / \mathrm{Kg})$ lower scores were observed as present in Table 3, the results of the arthritic score for curative and prophylactic phase was significant $(\mathrm{P}<0.05)$.

\section{Effect on Biochemical Parameters}

The results for BUN showed significant $(\mathrm{P}<0.05)$ increase in $400 \mathrm{mg} / \mathrm{Kg}$ dose, than $200 \mathrm{mg} / \mathrm{Kg}$ dose and standard in prophylactic phase when compared to normal control present in Table 4. The results for creatinine showed significant $(\mathrm{P}<$ 0.05 ) increase in $400 \mathrm{mg} / \mathrm{Kg}$ dose and standard, than $200 \mathrm{mg}$ / Kg dose in prophylactic phase. In the curative phase there is a significant $(\mathrm{P}<0.05)$ increase in both the dose and standard when compared to normal control present in Table 4. Results for total protein showed significant $(\mathrm{P}<0.05)$ decrease in 200 $\mathrm{mg} / \mathrm{Kg}$ and $400 \mathrm{mg} / \mathrm{Kg}$ dose, than standard in prophylactic phase and curative phase when compared to normal control present in Table 4.

The results for ALT showed significant $(\mathrm{P}<0.05)$ increase in $200 \mathrm{mg} / \mathrm{Kg}$ dose, then standard in prophylactic phase and curative phase when compared to normal control present in Table 4. Results for AST showed significant $\left({ }^{*} \mathrm{P}<0.05\right)$ increase in $200 \mathrm{mg} / \mathrm{Kg}$ dose and standard, than $400 \mathrm{mg} / \mathrm{Kg}$ dose in prophylactic phase when compared to normal control present in Table 4.

The results for ALP showed significant $(\mathrm{P}<0.05)$ increase in $200 \mathrm{mg} / \mathrm{Kg}$ dose, than $400 \mathrm{mg} / \mathrm{Kg}$ dose and standard in prophylactic phase when compared to normal control present in Table 4. Results for CRP showed significant $\left({ }^{*} \mathrm{P}<0.05\right)$ increase in $200 \mathrm{mg} / \mathrm{Kg}$ dose and $400 \mathrm{mg} / \mathrm{Kg}$, than $400 \mathrm{mg} /$ $\mathrm{Kg}$ dose and standard in prophylactic phase and in curative phase significant $(\mathrm{P}<0.05)$ increase in $200 \mathrm{mg} / \mathrm{Kg}$ dose only when compared to normal control present in Table 4 .

The results for SOD showed significant $(\mathrm{P}<0.05)$ increase in $200 \mathrm{mg} / \mathrm{Kg}$ dose and $400 \mathrm{mg} / \mathrm{Kg}$, than standard in prophylactic phase and in curative phase significant $(\mathrm{P}<0.05)$ increase in $400 \mathrm{mg} / \mathrm{Kg}$ dose and standard when compared to normal control present in Table 5. Results for GSH showed significant $(\mathrm{P}<0.05)$ increase in $200 \mathrm{mg} / \mathrm{Kg}, 400 \mathrm{mg} / \mathrm{Kg}$, and standard in prophylactic phase and in curative phase significant $(\mathrm{P}<0.05)$ increase standard when compared to normal control present in Table 5. The results for LPO showed significant $(\mathrm{P}<0.05)$ increase in $400 \mathrm{mg} / \mathrm{Kg}$, and standard than $200 \mathrm{mg} / \mathrm{Kg}$ dose in prophylactic phase and in curative phase significant $(\mathrm{P}<0.05)$ increase in $200 \mathrm{mg} / \mathrm{Kg}, 400 \mathrm{mg} /$ $\mathrm{Kg}$ and standard when compared to normal control present in Table 5. Results for GPx showed significant $\left({ }^{*} \mathrm{P}<0.05\right)$ increase in $200 \mathrm{mg} / \mathrm{Kg}$, than standard and $200 \mathrm{mg} / \mathrm{Kg}$ dose in curative phase when compared to normal control present in Table 5. Results for protein showed significant $\left({ }^{*} \mathrm{P}<0.05\right)$ increase in 200 and $400 \mathrm{mg} / \mathrm{Kg}$, than standard in prophylactic phase and $200 \mathrm{mg} / \mathrm{Kg}$ curative phase when compared to normal control present in Table 5. 
TNF-Alpha and IL-6 Assays

Quantitative real-time polymerase chain reaction (PCR) analysis of TNF-alpha and IL-6 mRNA expression in c-MIRtreated and control group synovial tissues showed that the expression of TNF-alpha and IL-6 increased prophylactically in a dose-dependent manner and is reversed in the curative phase of EAESC relative to the norm shown in Figure 1.

\section{Histopathological Changes}

To assess the general histopathological alterations, the H\&E stained left tibiotarsal joints of rats from all the groups were examined. The left tibio-tarsal joints of all control group rats showed normal histology of the joint with no signs of arthritis as shown in Figure 2.

Complete Freund's adjuvant injected rats' tibiotarsal joints showed moderate to extreme proliferative synovitis with severe multifocal mononuclear cell infiltration marked by hyperplastic synovial membrane. In all rats in this group, pannus invasion into the synovial spaces, subchondral and cortical bone associated with moderate to severe multifocal cartilage deterioration and bone erosion was observed. In both the prophylactic and curative stages, meloxicam treated rats exhibited a normal synovium and articular cartilage with mild Mononuclear cell infiltration into the synovial stroma.

In the arthritic rats treated with a dose of $200 \mathrm{mg} / \mathrm{Kg}$ body weight (both prophylactic and curative phases), very mild hyperplastic synovium with few stromal inflammatory infiltrates, normal articular cartilage and normal bone architecture was observed. These changes were considerably smaller than those found in adjuvant-injected rats and were equivalent to those treated with meloxicam.

\begin{tabular}{|c|c|c|c|c|c|c|c|c|}
\hline \multicolumn{9}{|c|}{ Body Weight Changes (in \%) } \\
\hline \multirow[t]{2}{*}{ Group } & \multicolumn{4}{|c|}{ Prophylactic Phase } & \multicolumn{4}{|c|}{ Curative Phase } \\
\hline & $1 \mathrm{~W}$ & $2 W$ & $3 \mathbf{W}$ & $4 W$ & $1 \mathrm{~W}$ & $2 W$ & $3 \mathbf{W}$ & $4 W$ \\
\hline Normal & 4.22 & 5.10 & 7.33 & 8.80 & 4.22 & 5.10 & 7.33 & 8.80 \\
\hline $\begin{array}{c}\text { Arthritic } \\
\text { control }\end{array}$ & 2.21 & 10.67 & 7.1 & 6.16 & 2.21 & 10.67 & 7.1 & 6.16 \\
\hline $\begin{array}{c}\text { EAESC } \\
200 \mathrm{mg} / \\
\mathrm{Kg}\end{array}$ & 5.98 & 7.3 & 7.11 & 4.33 & 2.85 & 7.27 & 5.89 & 3.92 \\
\hline $\begin{array}{c}\text { EAESC } \\
400 \mathrm{mg} / \\
\mathrm{Kg}\end{array}$ & 3.15 & 8.45 & 4.86 & 1.91 & 2.45 & 7.78 & 4.35 & 3.30 \\
\hline \begin{tabular}{|c} 
Meloxicam \\
$0.1 \mathrm{ml} /$ \\
$\mathrm{Kg}$ \\
\end{tabular} & 3.23 & 4.11 & 4.21 & 4.54 & 3.90 & 4.22 & 3.33 & 3.12 \\
\hline \multicolumn{9}{|c|}{\begin{tabular}{|l|} 
Table 1. Effect of EAESC Bark on Animal Body Weight Changes \\
\end{tabular}} \\
\hline $\begin{array}{l}\text { Data are ex } \\
\text { Compared }\end{array}$ & $\begin{array}{l}\text { ressec } \\
\text { ith th }\end{array}$ & $\begin{array}{l}\text { mean } \\
\text { f arthri }\end{array}$ & $\begin{array}{l}\text { EM of } \\
\text { contr }\end{array}$ & nima & each & up. P & $05, \mathrm{P}$ & \\
\hline
\end{tabular}

\begin{tabular}{|ccc|}
\hline Group & $\begin{array}{c}\text { Arthritic Index Score } \\
\text { Prophylactic Phase }\end{array}$ & $\begin{array}{c}\text { Curative Phase } \\
\text { Normal }\end{array}$ \\
Arthritic control & $4.00 \pm 0.00$ & $0.00 \pm 0.00$ \\
EAESC $200 \mathrm{mg} / \mathrm{Kg}$ & $4.32 \pm 0.14$ & $4.80 \pm 0.12$ \\
EAESC $400 \mathrm{mg} / \mathrm{Kg}$ & $3.80 \pm 0.17^{*}$ & $4.50 \pm 0.15$ \\
Meloxicam $0.1 \mathrm{ml} / \mathrm{Kg}$ & $3.70 \pm 0.14^{* *}$ & $4.00 \pm 0.16^{*}$ \\
\hline \multicolumn{2}{|c|}{ Table 3. Effect of EAESC Bark on Arthritic Index Score } \\
\hline${ }^{*} \mathrm{P}<0.05,{ }^{* *} \mathrm{P}<0.01$ compared with arthritic control. \\
\hline
\end{tabular}

\begin{tabular}{|c|c|c|c|c|c|c|c|c|c|c|}
\hline \multirow[t]{3}{*}{ Group } & \multicolumn{10}{|c|}{ Paw Volume (in ml) } \\
\hline & \multicolumn{5}{|c|}{ Prophylactic Phase } & \multicolumn{5}{|c|}{ Curative Phase } \\
\hline & ow & $1 \mathrm{~W}$ & $2 \mathrm{~W}$ & $3 \mathrm{~W}$ & $4 W$ & ow & $1 \mathrm{~W}$ & $2 \mathrm{~W}$ & $3 \mathrm{w}$ & $4 W$ \\
\hline Normal & $1.28 \pm 0.03$ & $1.34 \pm 0.03$ & $1.29 \pm 0.03$ & $1.32 \pm 0.03$ & $1.33 \pm 0.02$ & $1.28 \pm 0.03$ & $1.34 \pm 0.03$ & $1.29 \pm 0.03$ & $1.32 \pm 0.03$ & $1.33 \pm 0.02$ \\
\hline Arthritic control & $1.27 \pm 0.04$ & $1.90 \pm 0.11^{*}$ & $2.10 \pm 0.06^{*}$ & $1.98 \pm 0.09^{*}$ & $1.96 \pm 0.09^{*}$ & $1.27 \pm 0.04$ & $1.90 \pm 0.11^{*}$ & $2.10 \pm 0.06^{*}$ & $1.98 \pm 0.09^{*}$ & $1.96 \pm 0.09 *$ \\
\hline EAESC $200 \mathrm{mg} / \mathrm{Kg}$ & $1.21 \pm 0.02$ & $\begin{array}{c}1.7221 \pm \\
0.06^{* *}\end{array}$ & $1.81 \pm 0.06^{* *}$ & $1.70 \pm 0.06^{* *}$ & $1.65 \pm 0.06^{* *}$ & $1.3221 \pm 0.03$ & $1.6821 \pm 0.03$ & $1.93 \pm 0.05^{* *}$ & $1.74 \pm 0.03^{* *}$ & $1.70 \pm 0.03^{* *}$ \\
\hline EAESC 400 mg / Kg & $1.91 \pm 0.02$ & $1.60 \pm 0.06^{* *}$ & $1.68 \pm 0.06^{* *}$ & $1.63 \pm 0.06^{* *}$ & $1.58 \pm 0.06^{* *}$ & $1.32 \pm 0.03$ & $1.64 \pm 0.04^{* *}$ & $1.92 \pm 0.03^{* *}$ & $1.66 \pm 0.03^{* *}$ & $1.61 \pm 0.03^{* *}$ \\
\hline Meloxicam $0.1 \mathrm{ml} / \mathrm{Kg}$ & $1.20 \pm 0.04$ & $1.57 \pm 0.06^{* *}$ & $1.65 \pm 0.05^{* *}$ & $1.57 \pm 0.05^{* *}$ & $1.48 \pm 0.05^{* *}$ & $1.23 \pm 0.03$ & $1.60 \pm 0.06^{* *}$ & $1.88 \pm 0.06^{* *}$ & $1.65 \pm 0.04^{* *}$ & $1.56 \pm 0.07^{* *}$ \\
\hline \multicolumn{11}{|c|}{ Table 2. Effect of EAESC Bark on Paw Volume on CFA Induced Arthritic in Rats } \\
\hline
\end{tabular}

\begin{tabular}{|c|c|c|c|c|c|c|c|c|}
\hline \multirow[b]{2}{*}{ Parameters } & \multirow[b]{2}{*}{ Normal Control } & \multirow[b]{2}{*}{ Arthritic Control } & \multicolumn{3}{|c|}{ Prophylactic Phase } & \multicolumn{3}{|c|}{ Curative Phase } \\
\hline & & & $200 \mathrm{mg} / \mathrm{Kg}$ & $400 \mathrm{mg} / \mathrm{Kg}$ & $\begin{array}{c}\text { Meloxicam } 0.1 \mathrm{ml} \\
/ \mathrm{Kg}\end{array}$ & $200 \mathrm{mg} / \mathrm{Kg}$ & $400 \mathrm{mg} / \mathrm{Kg}$ & $\begin{array}{c}\text { Meloxicam } 0.1 \mathrm{ml} \\
\text { / Kg }\end{array}$ \\
\hline BUN & $23.46 \pm 0.63$ & $28.83 \pm 0.53^{* *}$ & $26.36 \pm 0.7^{* *}$ & $26.07 \pm 0.31 *$ & $26.31 \pm 0.77^{* *}$ & $27.63 \pm 0.55^{* *}$ & $26.56 \pm 0.50^{* *}$ & $26.3 \pm 0.43^{* *}$ \\
\hline Creatinine & $1.23 \pm 0.04$ & $1.89 \pm 0.27^{* *}$ & $1.77 \pm 0.04^{* *}$ & $1.73 \pm 0.03^{*}$ & $1.69 \pm 0.04 *$ & $1.72 \pm 0.03 *$ & $1.71 \pm 0.02^{*}$ & $1.69 \pm 0.04^{*}$ \\
\hline Total Protein & $6.32 \pm 0.41$ & $9.76 \pm 0.32^{* *}$ & $8.17 \pm 0.55^{*}$ & $8.07 \pm 0.32^{*}$ & $7.88 \pm 0.45$ & $8.06 \pm 0.48^{*}$ & $7.89 \pm 0.33^{*}$ & $7.64 \pm 0.18$ \\
\hline ALT & $22.41 \pm 0.44$ & $29.88 \pm 3.32^{* *}$ & $28.37 \pm 0.68^{*}$ & $27.45 \pm 0.71$ & $27.06 \pm 0.44$ & $27.85 \pm 0.33^{*}$ & $27.39 \pm 0.91$ & $27.18 \pm 0.22$ \\
\hline AST & $79.12 \pm 0.26$ & $88.24 \pm 0.95^{* *}$ & $87.14 \pm 0.82^{* *}$ & $86.15 \pm 0.23^{* *}$ & $84.30 \pm 1.37^{*}$ & $86.73 \pm 1.23^{* *}$ & $84.95 \pm 1.72^{* *}$ & $84.24 \pm 1.798^{*}$ \\
\hline ALP & $215.02 \pm 7.65$ & $475.02 \pm 6.87^{* *}$ & $259.59 \pm 10.80^{*}$ & $252.34 \pm 13.46$ & $233.2 \pm 13.97$ & $268.1 \pm 8.11^{* *}$ & $249.66 \pm 7.32$ & $241.68 \pm 15.02$ \\
\hline CRP & $3.12 \pm 0.18$ & $5.02 \pm 0.30^{* *}$ & $3.69 \pm 0.01^{*}$ & $3.69 \pm 0.02^{*}$ & $3.62 \pm 0.05$ & $3.67 \pm 0.04^{*}$ & $3.66 \pm 0.03$ & $3.59 \pm 0.04$ \\
\hline \multicolumn{9}{|c|}{ Table 4. Effect on Biochemical Parameters in Blood } \\
\hline
\end{tabular}

\begin{tabular}{|c|c|c|c|c|c|c|c|c|}
\hline \multirow[b]{2}{*}{ Parameters } & \multirow[b]{2}{*}{ Normal Control } & \multirow[b]{2}{*}{ Arthritic Control } & \multicolumn{3}{|c|}{ Prophylactic Phase } & \multicolumn{3}{|c|}{ Curative Phase } \\
\hline & & & $200 \mathrm{mg} / \mathrm{Kg}$ & $400 \mathrm{mg} / \mathrm{Kg}$ & $\begin{array}{c}\text { Meloxicam } 0.1 \mathrm{ml} \\
\text { / Kg }\end{array}$ & $200 \mathrm{mg} / \mathrm{Kg}$ & $400 \mathrm{mg} / \mathrm{Kg}$ & $\begin{array}{c}\text { Meloxicam } 0.1 \mathrm{ml} \\
\text { / Kg }\end{array}$ \\
\hline SOD & $0.35 \pm 0.02$ & $0.11 \pm 0.006^{* *}$ & $0.26 \pm 0.005^{*}$ & $0.25 \pm 0.005^{*}$ & $0.24 \pm 0.006$ & $0.26 \pm 0.006$ & $0.26 \pm 0.005^{*}$ & $0.25 \pm 0.02 *$ \\
\hline GSH & $3.13 \pm 0.008$ & $1.03 \pm 0.15^{* *}$ & $2.41 \pm 0.29^{*}$ & $2.4 \pm 0.07^{*}$ & $2.4 \pm 0.09^{*}$ & $2.49 \pm 0.13$ & $2.48 \pm 0.04$ & $2.46 \pm 0.05^{*}$ \\
\hline LPO & $0.11 \pm 0.008$ & $0.24 \pm 0.04^{* *}$ & $0.23 \pm 0.02^{* *}$ & $0.22 \pm 0.02^{*}$ & $0.22 \pm 0.03^{*}$ & $0.22 \pm 0.02^{*}$ & $0.21 \pm 0.01^{*}$ & $0.21 \pm 0.005^{*}$ \\
\hline GPX & $8.55 \pm 0.32$ & $17.93 \pm 0.65^{* *}$ & $11.28 \pm 0.66^{* *}$ & $10.12 \pm 0.06$ & $10.02 \pm 0.39$ & $10.66 \pm 0.59^{*}$ & $10.51 \pm 0.32$ & $10.26 \pm 0.53$ \\
\hline PROTEIN & $116.76 \pm 3.51$ & $164.37 \pm 5.94^{* *}$ & $155.94 \pm 16.53^{*}$ & $152.58 \pm 13.60^{*}$ & $151.01 \pm 1.20$ & $152.09 \pm 6.52 *$ & $151.04 \pm 2.41$ & $150.73 \pm 0.47$ \\
\hline \multicolumn{9}{|c|}{ Table 5. Effect on Antioxidant Parameters in Liver } \\
\hline
\end{tabular}


In rats treated with $400 \mathrm{mg} / \mathrm{Kg}$ body weight, the degree of synovial proliferation, mononuclear cells (MNC) infiltration and pannus formation was moderate compared to that of adjuvant-injected rats. These results indicate that the pathological progression of adjuvant induced arthritis is suppressed by a 28-day EAESC therapy at a dosage of $200 \mathrm{mg}$ / Kg / body weight.

\section{DISCUSSION}

Rheumatoid arthritis (RA) is a chronic inflammatory disorder of probable autoimmune origin, characterized by symmetric synovial joint inflammation that can lead to cartilage and bone damage and progressive loss of function. ${ }^{27}$ Nonsteroidal antiinflammatory medications, glucocorticoids, and diseasemodifying anti-rheumatic drugs are the treatment choice for RA. These drugs, when used by patients show a lot of unnecessary side effects which created the need to look for new, efficient and safe therapeutic agents. Interestingly, a number of herbs and other natural products provide a vast resource for the treatment of arthritis. ${ }^{28} \mathrm{CFA}$ induced arthritic model is considered as a chronic, immunological, cellular and proliferative arthritis similar to clinical RA.

There are two phases of this model: An acute phase and chronic phase. The acute phase starts from day 0 followed by a chronic inflammatory phase from day 15 . The chronic phase is marked by inflammatory oedema in the contralateral noninjected paw. ${ }^{29}$ The leucocytes migrate into the affected area and cause acute oedema by the release of cytokines like IL-1 $\beta$, prostaglandins, TNF-alpha, histamine and serotonin. The chronic phase is a consequence of cell-mediated immunity and causes the degenerative changes in cartilage and bone.

The animals induced arthritis showed high arthritic index score and increased swelling on the paw in both prophylactic and curative phase. The treatment with EAESE showed reduction in arthritic index and paw swelling which showed the extract possess anti-arthritic activity. Inhibition of paw swelling was associated with inhibition of both TNF-alpha, IL$1 \beta$, and IL- 6 cytokine production and cell infiltration, as analysed in the subcutaneous tissues of the paw. ${ }^{30}$

Change in body weight in the animals induced with CFA is a response to evaluate the drug and the duration of inflammation. ${ }^{31}$ The inflammation resulted from the arthritis is more in the CFA induced animals than normal animals. There is a protection seen in the reduction of body weight to EAESE treated animals which shows the EAESE possess antiinflammatory activity. CFA damages the liver architecture and release the enzymes into the circulation thus liver enzymes were elevated in the adjuvant inducted group. ${ }^{32}$ The liver enzymes were not elevated in the EAESE treated group which shows the extract possess protection on liver damage. Literature evidence shows that $S$. colais possess protective effect on liver damage thus correlating our observation.

Several studies have confirmed that the environment that drives cartilage and bone degradation is pro-inflammatory cytokines, particularly tumour necrosis factor TNF- $\alpha$, interleukin (IL)-1, IL-6, IL-17 and mediators generated via downstream pathways in the arthritic joints. ${ }^{33}$ The arthritic group elevated the cytokines level and the same was reversed in the EAESC treated rats which showed the extract exhibits the reduction of inflammation by (TNF)- $\alpha$ via reactive oxygen species (ROS) levels reduction.

The main role of reactive oxygen species is deterioration of lipids through a metabolic process known as lipid peroxidation. This may significantly affect cell membrane structure and function. It has been involved in cancer, atherosclerosis, degenerative disorders, and inflammatory arthritis pathogenesis. ${ }^{34}$ The arthritic group showed reduction in lipid peroxidation (LPO) due to destruction of cell membrane leading to over production of ROS. The antioxidant property is evident in this study as the EAESC treated group of rats showed protection in reduction in LPO when compared to arthritic control.

Superoxide dismutase (SOD), catalase and glutathione peroxidase are the enzymatic antioxidant defence mechanisms, that protect the cells against 02 toxicity and lipid peroxidation. ${ }^{35}$ Our study findings indicate that SOD and glutathione peroxidase activities have been found to decrease in arthritic animals, which may be due to the huge and rapid increase of free radicals. Superoxide anions are thought to be involved in inflammatory reactions because phagocytic cells produce them and are known to generate radical hydroxyl and singlet oxygen. ${ }^{36}$ Glutathione peroxidase is found in the cytoplasm and mitochondria, which, with the formation of its conjugates, catalyses the degradation of different peroxides by oxidizing glutathione. ${ }^{37}$

The treatment with EAESC for arthritis showed progress and effectiveness in relation to histopathological studies. Therapy with EAESC decreased the cellular invasion, oedema formation and inflammation in rats with induced arthritis. The overall results of the study indicate that EAESC can prevent arthritis and decrease inflammation and joint destruction in animals with induced rheumatoid arthritis.

\section{CONCLUSIONS}

Ethyl acetate extract of bark of Stereospermum colais $(200 \mathrm{mg}$ / Kg and $400 \mathrm{mg} / \mathrm{Kg}$ body weight) showed anti-arthritic properties similar to those observed for non-steroidal antiinflammatory drug. It justifies the use of the stem bark of this plant by traditional medicinal practitioner in the treatment of rheumatism and inflammatory diseases. Phytochemical analysis of EAESC of stem bark showed the presence of flavonoids and phenol. Thus, it is proved that the aforesaid pharmacological action of EAESC is largely due to the presence of one or more bioactive compounds such a flavonoids and phenols.

Data sharing statement provided by the authors is available with the full text of this article at jemds.com.

Financial or other competing interests: None.

Disclosure forms provided by the authors are available with the full text of this article at jemds.com.

We sincerely thank the management of Sri Ramachandra Institute of Higher Education and Research (SRIHER), Chennai-116. 


\section{REFERENCES}

[1] Silman AJ, Pearson JE. Epidemiology and genetics of rheumatoid arthritis. Arthritis Res 2002;4(Suppl 3):S265S72.

[2] Myasoedova E, Crowson CS, Kremers HM, et al. Is the incidence of rheumatoid arthritis rising? results from Olmsted County, Minnesota, 1955-2007. Arthritis Rheum 2010;62(6):1576-82.

[3] Rindfleisch JA, Muller D. Diagnosis and management of rheumatoid arthritis. Am Fam Physician 2005;72(6):1037-47.

[4] Ostrowska M, Maśliński W, Prochorec-Sobieszek M, et al. Cartilage and bone damage in rheumatoid arthritis. Reumatologia 2018;56(2):111-20.

[5] Chemin K, Gerstner C, Malmström V. Effector functions of $\mathrm{CD} 4+\mathrm{T}$ cells at the site of local autoimmune inflammationlessons from rheumatoid arthritis. Front Immunol 2019;10:353.

[6] Kinne RW, Bräuer R, Stuhlmüller B, et al. Macrophages in rheumatoid arthritis. Arthritis Res 2000;2(3):189-202.

[7] Durie FH, Fava RA, Noelle RJ. Collagen-induced arthritis as a model of rheumatoid arthritis. Clin Immunol Immunopathol 1994;73(1):11-8.

[8] Soto H, Hevezi P, Roth RB, et al. Gene array analysis comparison between rat collagen-induced arthritis and human rheumatoid arthritis. Scand J Immunol 2008;68(1):43-57.

[9] Mathiessen A, Conaghan PG. Synovitis in osteoarthritis: current understanding with therapeutic implications. Arthritis Res Ther 2017;19(18).

[10] Quan LD, Thiele GM, Tian J, et al. The development of novel therapies for rheumatoid arthritis. Expert Opin Ther Pat 2008;18(7):723-38.

[11] Wojdasiewicz P, Poniatowski ŁA, Szukiewicz D. The role of inflammatory and anti-inflammatory cytokines in the pathogenesis of osteoarthritis. Mediators Inflamm 2014;2014:561459.

[12] Prema S, Saraswathi A, Chitra K, et al. A review on Stereospermum colais Mabb: bignoniaceae. Int J Pharm Sci Rev Res 2013;21(1):314-7.

[13] Mishra LC. Scientific basis for ayurvedic therapies. India: CRC Press 2004: p. 24.

[14] Raju V, Reddy KN. Ethnomedicine for dysentery and diarrhoea from Khammam district of Andhra Pradesh. Indian J Traditional Knowledge 2005;4(4):443-7.

[15] Rajesh P, Kumar NR. Evaluation of analgesic activity on methanolic extract fractions of Stereospermum colais stem bark. Pharmanest 2011;2(2-3):244-50.

[16] Bharathi RV, Suresh AJ, Veni BK, et al. In vitro antibacterial and antifungal studies of stereospermum colai leaf extracts. International Journal of Pharmacy \& Technology 2010;2(3):603-11.

[17] Bharathi RV, Veni BK, Jayashree, et al. Antioxidant and wound healing studies on different extracts of Stereospermum colais leaf. Int J Res Pharma Sci 2010;1(4):435-9.

[18] Prema S, Saraswathy A, Chitra K, et al. Preliminary phytochemical evaluation and quantification of metabolites of Stereospermum colais bark. The Journal of Phytochemistry 2014;115:253-60.
[19] Warrier PK, Nambiar VPK, Ramankutty C. Indian medicinal plants-a compendium of 500 species. Chennai: Orient Longman 2002: p. 5.

[20] Mukerjee PM. Quality conrol of herbal drugs India. 2005:273-4.

[21] OECD guidelines for the testing of chemicals. (Acute oral toxicity-Up and Down procedure (UDP)) https://www.oecd-

library.org/docserver/9789264071049en.pdf?expires=1 582181643\&id=id

$\&$ ccname=guest $\&$ checksum $=690641$ D52652246613FE53 D1A902FD45

[22] Pearson CM. Development of arthritis, periarthritis and periostitis in rats given adjuvants. Experimental Biology and Medicine 1956;91(1):95-101.

[23] Fereidoni M, Ahmadiani A, Semnanian S, et al. An accurate and simple method for measurement of paw edema. J Pharmacol Toxicoll Methods 2000;43(1):11-4.

[24] Wooley PH, Luthra HS, Stuart JM, et al. Type II collageninduced arthritis in mice. I. Major histocompatibility complex (I region) linkage and antibody correlates. J Exp Med 1981;154(3):688-700.

[25] Guingamp C, Gegout-Pottie P, Philippe L, et al. Monoiodoacetate-induced experimental osteoarthritis. a doseresponse study of loss of mobility, morphology and biochemistry. Arthritis Rheum 1997;40(9):1670-9.

[26] Boyle DL, Kowaluk EA, Jarvis MF, et al. Anti-inflammatory effects of ABT-702, a novel non-nucleoside adenosine kinase inhibitor, in rat adjuvant arthritis. J Pharmacol Exp Ther 2001;296(2):495-500.

[27] Guo Q, Wang Y, Xu D, et al. Rheumatoid arthritis: pathological mechanisms and modern pharmacologic therapies. Bone Res 2018;6:15.

[28] Dudics S, Langan D, Meka RR, et al. Natural products for the treatment of autoimmune arthritis: their mechanisms of action, targeted delivery and interplay with the host microbiome. Int J Mol Sci 2018;19(9):2508.

[29] Narendhirakannan RT, Subramanian S, Kandaswamy M. Anti-inflammatory and lysosomal stability actions of Cleome gynandra L. studied in adjuvant induced arthritic rats. Food Chem Toxicol 2007;45(6):1001-12.

[30] Ross SE, Williams RO, Mason LJ, et al. Supression of TNF$\alpha$ expression, inhibition of Th1 activity and amelioration of collagen-induced arthritis by Rolipram. J Immunol 1997;159(12):6253-9.

[31] Naik SR, Wala SM. Arthritis, a complex connective and synovial joint destructive autoimmune diseases: animal models of arthritis with varied etiopathology and its significance. J Postgrad Med 2014;60(3):309-17.

[32] Contreras-Zentella ML, Hernández-Muñoz R. Is liver enzyme release really associated with cell necrosis induced by oxidant stress? Oxid Med Cell Longev 2016;2016:3529149.

[33] Alunno A, Carubbi F, Giacomelli R, et al. Cytokines in the pathogenesis of rheumatoid arthritis: new players and therapeutic targets. BMC Rheumatol 2017;1:3.

[34] Ayala A, Muñoz MF, Argüelles S. Lipid peroxidation: production, metabolism and signaling mechanisms of malondialdehyde and 4-hydroxy-2-nonenal. Oxid Med Cell Longev 2014;2014:360438.

[35] Ighodaro OM, Akinloye OA. First line defence antioxidants-superoxide dismutase (SOD), catalase (CAT) 
and glutathione peroxidase (GPX): their fundamental role in the entire antioxidant defence grid. Alexandria Journal of Medicine 2018;54(4):287-93.

[36] Kontos HA, Wei EP, Ellis EF, et al. Appearance of superoxide anion radical in cerebral extracellular space during increased prostaglandin synthesis in cats. Circ Res 1985;57(1):142-51.

[37] Lubos E, Loscalzo J, Handy DE. Glutathione peroxidase-1 in health and disease: from molecular mechanisms to therapeutic opportunities. Antioxid Redox Signal 2011;15(7):1957-97. 